Review Article

\title{
Promotion of mental health and well-being in Indian prisons
}

\author{
Arjyalopa Mishra*, Amartya Shreya, Anuj Shukla
}

Department of Management, National Law University, Cuttack, Odisha, India

Received: 10 October 2020

Revised: 10 December 2020

Accepted: 17 December 2020

*Correspondence:

Dr. Arjyalopa Mishra,

E-mail: arjyalopa@nluo.ac.in

Copyright: (C) the author(s), publisher and licensee Medip Academy. This is an open-access article distributed under the terms of the Creative Commons Attribution Non-Commercial License, which permits unrestricted non-commercial use, distribution, and reproduction in any medium, provided the original work is properly cited.

\begin{abstract}
Decades of study on prison sociology have sought answers to questions pertaining to the social organization of the prison community. Various researchers expressed their opinion, stating that incarceration has a negative psychological impact. Indian Prisons framework it is seen that the penitentiaries are exceptionally stuffed, this in a situation where the crime percentage has expanded alarmingly which further extends the overburdened detainment facilities. This study is aims to review the documentation of committee reports which were attempts to observe the changes in the Indian Prison Structure. It also makes an attempt to explore the behavior, cognitions and emotional adjustments as different variables in understanding the adaptation process in the Prison set up. Overall, it also attempts to highlight the state of wellbeing and promotion of mental health in the Indian Correctional Systems as major reforms to be incorporated.
\end{abstract}

Keywords: Mental health, Correctional systems, Indian prisons, Prison reforms

\section{INTRODUCTION}

Correctional systems are an essential component of an effective criminal justice system. It not only supports law enforcement, but also promotes humanely managing individuals in conflict with the law and to reform themselves by providing opportunities for rehabilitation and successfully integrating them back into society. ${ }^{1}$ Detainees are at expanded danger of mental sick wellbeing, with penitentiaries conceivably at genuine risk of turning out to be refuges for the intellectually sick (WHO, 2008). Universally, at any rate $1,000,000$ detainees experience the ill effects of a huge mental issue, with fundamentally additionally experiencing sorrow and uneasiness (WHO, 2008). Those imprisoned in jails are likewise at expanded danger for psychological well-being messes and self-destructive ideation at a rate excessively higher than in the overall network. Many explorations have exhibited the structure of analysis of the advanced remedial organization. It is made out of six perceptions which, taken together, unremittingly upbraid "the disappointment" of jail to play out the capacities formally allotted to it at various periods. In addition to the existing knowledge researchers have also identified and designed specific tools required for correctional services like the motivational interviewing training, therapies and simulations for recovery in correctional homes in western countries but India still struggles to promote Mental Health and Wellbeing behind the bars. ${ }^{2}$

The Supreme Court in the case of D. Bhuvan Mohan Patnaik vs. State of Andhra Pradesh (1974 AIR 2092, 1975 SCR (2) 24) held that, "Convicts are not, by mere reason of the conviction, denuded of all the fundamental rights which they otherwise possess. A compulsion under the authority of law, following upon a conviction, to live in a prison- house entails by its own force the deprivation of fundamental freedoms like the right to move freely throughout the territory of India or the right to practice a profession.".

The Apex Court in the case of Sunil Batra (II) vs. Delhi Administration (1980 AIR 1579, 1980 SCR (2) 557) and 
Kishore Singh Ravinder Dev vs. State of Rajasthan (1981 AIR 625, 1981 SCR (1) 995) has iterated that "We cannot agree that either the Section or the Rules can be read in the absolutist expansionism the prison authorities would like us to read. That would virtually mean that prisoners are not persons to be dealt with at the mercy of the prison echelons. This country has no totalitarian territory even within the walled world we call prison. Articles 14, 19 and 21 operate within the prisons".

\section{HISTORICAL BACKGROUND IN RELATION TO PRISON REFORMS}

A persistent criticism was observed for the manner of functioning of prison systems in India, since 1980. Along with the fact, that they did not meet the international standards of human dignity and remain unmatched with the protection of fundamental rights of prison inmates. To give effect to this cause, the All-India Committee on Jail reforms, committee under the chairmanship of Mr. Justice A. N. Mulla was set up. This committee was commonly known as the Mulla Committee. Prominent recommendations were adequate and necessary arrangements to be made for food, clothing, ventilation, sanitation and hygiene etc. of the prison inmates to improve the conditions of the prisons. Also, integral part of prison service should include after-care, rehabilitation and probation. An advisory was made to constitute The Indian Prisons and Correctional Service for recruitment of Prison Officials, an All-India Service, where training for prison staff can be done and they can be categorized into different cadres. Under trial prisoners should be kept in separate prisons then from convicted prisoners. Population of under trials constitutes a sizable portion in prisons which can be reduced by speedy trials and easy to get bail provisions. Thus, there should be reduction in lodging of under trials in jail to the minimum. ${ }^{3}$ The Government of India should provide sufficient funds and adequate resources to bring about these Prison reforms.

These were some of the significant recommendations of the committee which are just advisory in nature. Thus, some of them were partly adopted, however the purpose of punishment and reforms to achieve this purpose remain the relevant matter to be discussed upon.

In 1987, a report was submitted by Justice V. R. Krishna Iyer Committee on Women prisoners, named The National Expert Committee on Women Prisoners. The committee was constituted to deal with the issues pertaining to the women prisoners as marginalized groups. Several recommendations were made by the committee for women prisoner inmates. Some of them were Necessary provisions to be made by the government to restore the dignity of women prisoners even if they are convicted under the criminal code. But, these recommendations of the committee were not accepted and adopted on a full-scale basis.
The $78^{\text {th }}$ Law Commission report of 1979 in particular dealt with congestion of under-trial prisoners in jails and their rights.

In 2007, a National Policy on Prison Reforms and Correctional Administration was framed by the Bureau of Police Research and Development (BPR\&D). The policy elaborates the need of medical and clinical facilities that should be provided to a prison inmate till their period of confinement. This may include a dispensary or a hospital in each prison with $24 * 7$ medication facilities and specialized treatments.

Later, a three-member committee was formed by the Hon'ble Supreme Court in Inhuman Conditions in 1382 Prisons (WP(C) No. 406 of 2013). The committee is headed by Justice Amitava Roy to suggest reforms in management and administration of prisons in India. Prominent observations were made by the committee. Some of them were human rights violations equally by prisoners and guards, unhygienic and poor conditions of prison kitchens and unchanged diet for years remain the same, common bane in understaffed prisons is overcrowding. This unwarranted phenomenon can be solved by the remedy of speedy trials. There should be at least one lawyer for every 30 prisoners. This is because of the disproportionate number of under-trial prisoners then convicted one. ${ }^{4}$ Using video-conferencing as a medium for trial which will reduce the need for escort and transportation by police guards for physical production of prisoners in courts.

\section{LEGAL AID IS ANOTHER BIGGEST ISSUE OF CONCERN FOR WOMEN PRISONERS}

Ministry of Women and Child Development (MWCD) in a report recommended that those women prisoners, who have completed their third of the term of conviction, should be released on bail provisions. ${ }^{5}$ Apart from that, women prison inmates do face other issues in crowded prisons. Legal aid is not available to these women. Flavia Agnes, advocate and social activist, in her recent article stated that "Poor Women Prisoners cannot afford bail for themselves and nobody in their families is bothered about them when they are in jail. They usually don't get support from their families. It is extremely sad to see that not much is being done for the women inmates". She further added that, "Majority of these women offenders are charged for offences like theft, domestic violence and human trafficking. On the other side they belong to economically poor families who are not keen to spend money on them to help them in getting bail."

In the case of Sheela Barse vs State of Maharashtra (JT 1988 (3) 15), the Supreme Court felt dire need to form a mechanism to provide legal assistance and other aids to prisoners in jails. The circular was issued requiring the authorities to - 
Prepare a list of under trial prisoners and send it to district legal aid committee. Also, providing advocates to the arrested persons. Providing notice at prominent places in jail to inform that persons from legal aid committee would be visiting on specific days and prisoners can meet them. Male and female prisoners to be kept separately in different prisons. ${ }^{6}$

\section{A REVIEW OF THE PRISON MANUAL 2016}

The new model of Prison Manual, approved by Union Home Minister Shri Rajnath Singh, has 32 chapters. The objective of the manual is to bring about a uniformity in rules, laws and regulations which governs the administration and management of prisoners in the country. Key provisions of the manual include access to free legal services, additional provisions for women prisoners and their children, rights of prisoners sentenced to death, along with modernization and prison computerization and inspection of prisons. Article 39A of the Indian Constitution provides for free legal aid to the poor and the weaker sections of the society which the earlier version of 2003 manual lacks. Thus, new modifications have been incorporated which include appointment of advocates prior their visits to jail, setting up of under trial review committee, legal aid clinic in every prison and legal services for those under trial prisoners who have completed half or more than that of maximum sentence for the offence they are charged with. Even if mercy petition is rejected, prisoners, sentenced to death, should be provided with legal aid at all stages.

Along with safety and reformation of women prisoners, health is also of utmost significance in prison administration and was imbedded in manual with provisions for compulsory health screening and tests for women prisoners to check Mental Health, drug dependency or any sexually transmitted diseases etc. ${ }^{7}$ Also, Training and workshops to be conducted for gender issues and sexual violence along with sensitizing the prison staff along with counselling sessions for those women prisoners suffering from psychological disorders and educating women on health care methods. Special care to women who are victims of abuse and focused rehabilitation measures for better and easy reintegration of women prison inmates into the society was also included. ${ }^{8}$ Punishments awarded to women should be restricted in the sense that close confinement punishment should not be given to women with infants or a pregnant woman. Taking into consideration the unsatisfying condition of health and hygiene in the prisons, the Apex Court in the case of P.B.K. Mazdoor Samity vs. State of West Bengal ((1996) AIR SC 2426/(1996) 4 SCC 37) opined that providing adequate medical facilities for the people was an essential part of obligation undertaken by the Government of Welfare State. In the case of Rama Murthy vs. State of Karnataka (ILR 1986 KAR 3037) it was held by the court that the society's obligation towards prisoners' health for two reasons. One of these reasons was that prisoners do not enjoy the access to medical expertise as the free citizens and the second is the conditions of prisoner's incarceration expose them to more health hazards than free citizens.

Use of technology or software systems has been encouraged in the manual by introducing a Personal Information System which records the information relating to inmates. An electronic form register is to be maintained by the prison authorities. Also, following the Supreme Court's decision in case of D.K. Basu vs. State of West Bengal and Ors (1997 (1) SCC 416), directions to install CCTV cameras in kitchens, main gates, work sheds, high security enclosures etc. of prisons is given. This will prevent infringement of human rights.

With regards to children of women prisoners, Supreme Court in case of R.D. Upadhyay vs. State of Andhra Pradesh (AIR 1999 SC 2183, 1999 Cri LJ 3499, JT 1998 (6) SC 486, (1998) 5 SCC 696) took positive steps and issues guidelines which ensure holistic development of children of women prison inmates and pregnant prisoners inside the prisons. Additional provisions in 2016 manual includes overall development children including food, educational, medical care, clothing and other recreational facilities, pregnant women prisoners to be given pre- and post-natal care, provisions for clean and safe drinking water and proper nutritional requirements of children and setting up well equipped crèche and a nursery school, to look after the children. Senior prison officers should carry out informal inspections and designated Inspector Officer to carry out formal inspection of prisons. The latter is a more detailed inspection which covers facilities relating to mess, medical care, security, hygiene etc. and would be reviewed by prison authorities. Thus, it would help to identify the issues and deficiencies if any, which can be solved by taking appropriate actions.

\section{ADDRESSING MENTAL HEALTH ISSUES AND POSSIBLE SOLUTIONS}

\section{Physical Conditions of Prisons: Infrastructure, Overcrowding and Congestion, Hygienic Conditions}

According to the report "Prison statistics India 2017" released by the NCRB (National Crime Record Bureau) the population of inmates (which increases every year) is more than the capacity of the prisons. This leads to overcrowding. Under-trials constitute around two-third of the total population of the inmates. Moreover, only $68.8 \%$ of sanctioned posts in jail administration were filled, which highlights how the prison system also has a lack of man power to support its operations. ${ }^{9}$

The Centre can issue guidelines to the state to determine the rate of increase in the number of prisoners by examining the increase in the last 5 years, in Prison establishments at all three levels - the taluka level (Sub Jails), district level (District Jails), and central (sometimes called zonal/range) level (and Central Jails). Based on that, necessary change in the prison establishment in 
terms of infrastructure and the number of prison staff must be made.

\section{Increased risk of mental illness}

The disproportionately high rate of mental disorders in prisons is related to several factors: the widespread misconception that all people with mental disorders are a danger to the public; the general intolerance of many societies to difficult or disturbing behaviour; the failure to promote treatment, care and rehabilitation, and, above all, the lack of, or poor access to, Mental Health services. ${ }^{10}$ Many of these disorders may be present before admission to prison, and may be further exacerbated by the stress of imprisonment. However, mental disorders may also develop during imprisonment itself as a consequence of prevailing conditions and also possibly due to torture or other human rights violations. ${ }^{11}$

To tackle the aforementioned issue, a section 14 A can be added to the Prisons Act, 1894 to ensure the availability of psychosocial support and rationally prescribed psychotropic medication: if a prisoner is observed to be exhibiting certain behavioural pattern which, by the medical officer is assessed or observed to be symptom of a certain Mental Health disorder, an appropriate Mental Health professional must be appointed on the report of the medical officer, by the order of the superintendent, upon approval from the inspector general. ${ }^{12}$

A clause (4) can be added to section 24 of the Prisons Act, 1894, which mandates that, any mental disorder present before admission to prison must be recorded in the prisoner's history ticket which shall be taken into account when considering the prisoner's behaviour in future. Necessary directives must be made by the medical officer to prevent the condition from further exacerbating. Such directives must be implemented by the order of the superintendent, upon confirmation by higher authority as determined by the state government, if necessary.

\section{Necessary work Opportunity}

Although the Prison Manual, 2016 and various committee reports like the 300 pages long Amitava Roy Committee report, suggest that there must be engagement of prisoners, yet they fail to mention what opportunities lie ahead of them and which authority is to ensure equal opportunities provided to male and female prisoners.

A separate section in chapter VII of the prisoners Act, 1894 can be added which mandates the states to make necessary regulations under section 59 of the act, to provide the opportunity to work to all prisoners who wish to work.

Pursuant to the change in the Act, necessary changes in the Prison manual(s), providing the step-by-step details of work-opportunity related programmes, must also be made.

\section{Introducing offender profiling/criminal Profiling}

Psychopathology leading to criminal psychology was not very commonly studied until the late 1900 s, when it was for the first time very deeply studied by FBI agents John Douglas and Robert Ressler, who began working at the Bureau in the 1970s. Whilst searching for a method to combat the wave of serial murders which had wracked that decade, Douglas and Ressler came up with a novel idea. They decided to take a different approach and delve straight to the origin. They decided to interview some of the most notorious killers in the history of the United States. The agents hoped that interviewing these criminals would provide them with some insight into their psyches, and provide the FBI with a clearer picture of their motives. With this information, the nascent behavioural Science Unit of the FBI, at Quantico, could develop criminal profiling methods that would help them identify warning signs of a potential serial killer and catch them before it was too late. ${ }^{13}$ Their work had astounding results.

They were the ones who came up with the idea of organized and unorganized killers, and the ones who coined the term "Serial Killer". They later came up with a book on their research titled, Mind Hunter: Inside the FBI's Elite Serial Crime Unit. This book primarily focused on their empirical research conducted on various offenders convicted of multiple murders, which they later define as sequence killers and then term them as serial killers.

The offenders convicted of heinous crimes are individuals who were found to take to violence as a personal assertion to compensate for their own pathos, failure, and/or lack of purpose. Their inner despair could've been in conflict with their sense of personal grandiosity and unfulfilled entitlement, and want to gain name and fame through acts as the ones they commit as giving meaning to their lives and makes them think it is violence that only could prove and assert their power. These findings helped Douglas and Ressler come up with the concept of Offender Profiling/Criminal Profiling. ${ }^{14}$ These profiling systems helped the police in speedy investigation of criminal offences, because it gave an outline of the possible offender. We see multiple instances of such profiling-system developed by the governments in the USA, but it has not been adopted in India, where high rates of criminal offences are recorded with low rates of cases disposed of. An attempt to incorporate this method in Indian criminal justice system must be made, so that the current investigation methods can be enhanced, and crimes are solved more efficiently and speedily.

\section{Prison nurseries for the well-being of incarcerated mothers}

The concept of Prison Nursery Programs incorporated in the US, offers incarnated pregnant women prisoners a choice to keep their child with them and parent them 
while they serve their sentence. ${ }^{15}$ To get into these programs is a rigorous process; there are limited spots available, mothers must have non-violent convictions with no record of child abuse and it has to be roughly within 18 months, which is maximum amount a child can stay with his or her mother behind bars, of completing their sentence. Women prison inmates are provided with parenting classes, counselling classes on substance abuse, support groups etc. Also, complementary day care services are given to attend these classes along with vocational training. ${ }^{16}$ These classes play a significant role to these women prisoners and help them to reintegrate into the society upon their release. As a result, a reduction in recidivism rate has been found in these mothers once they are released.

No concept of Prison Nursery has been implemented or ever recommended. However, the Krishna Iyer Committee on Women Prisoners recommended that "Women Prisoners should be allowed to keep their children with them", but no further suggestion for upbringing of such children, the parental facilities to be provided or basic educational needs to be given has been specified in the law. Reports have shown that these Nurseries prove to be beneficial and help in promoting growth of children with reduction in recidivism rate. Thus, such Nurseries can be formed and a clause can be inserted in the Prison Manual which mandates the functioning of such Nurseries in Indian Prisons. Guidelines can be issued by the Ministry of Home Affairs for the executive to work towards the effectual implementation of the provision of these facilities. ${ }^{17}$

\section{Rights of child in case both parents are convicted}

According to the National Crime Records Bureau's Prison Statistics India Snapshots - 2012, 1,394 existing prisons housed 385,135 inmates in the country. There was a total of 344 women convicts with their 382 children and 1,226 women awaiting trial with their 1,397 children lodged in various prisons in the country. ${ }^{18}$

According to the guidelines issued by the Apex court in the case of R.D. Upadhyaya vs. State of Andhra Pradesh (AIR 1999 SC 2183, 1999 Cri LJ 3499, JT 1998 (6) SC 486, (1998) 5 SCC 696). Children living in prisons with their mothers should not be ill-treated and should not be tagged as detainees or convicts. Children of incarnated parents must be provided with food, clothing, good hygiene, separate utensils, adequate sleeping facilities and other necessary facilities for their healthy development. Children up to age of 6 years can remain with their mothers in prison and later can be placed with surrogate mothers, if wished upon. Also, care can be taken by a $n$ institution maintained by the Social Welfare Department. These children must also be provided with the educational and recreational facilities. They are entitled to medical care and vaccinations. A good medical care has to be taken of these children in prisons.
Following the Supreme Court ruling in R.D. Upadhyaya vs. State of Andhra Pradesh (1999. 4 SCC 437), Indian Prisons must "provide crèches for children under three and nurseries for children aged three to six." Moreover, jurisdictions of various states and union territories have provided financial support for those children. Also, educational institutions must provide benefits to these children in terms of relaxation in fees and other infrastructural discourses. But since there is no review mechanism incorporated in the law owing to which there exist limitations in the implementation.

\section{Good Behaviour a criteria for reducing/commuting punishment of prisoners}

Section 433 of the Cr. P, C. authorizes government authorities to commute or reduce the form of punishment given to a convict by the courts and they are not answerable to courts for such decisions. In such cases there is no check and balance situation where the Judicial wing has no say in these cases. In recent observations made by CJI S. A. Bobde along with Justices S. Abdul Nazeer and Sanjiv Khanna reported that all mitigating circumstances have been looked into by the court at the trial stage and thus post-conviction "Good Behaviour" in jail may not be taken as a sufficient and valid ground to modify or alter a death sentence. The punishment given by the court is sort of societal expectations and depends upon the gravity and nature of crime. Court in no sense is against reformation. In the case of Shatrughan Chauhan, the court validly and lawfully passed the order of death sentence. Thus, its execution must also be in consonance with constitutional mandate and one which does not violate the constitutional principles.

The list of supervening factors given by the court in the case is not an exhaustive one. But in all, what needs to be looked before Good Behaviour is the gravity and nature of crime. In certain offences like Rape, Murder, offences against Government like sedition, against nation like terrorism should have no room for commutation of punishment. It is because already a lot of resources and time has been invested by the courts in deciding a case and again reviewing such decisions by administrative wing is unnecessary.

Moreover, the term Good Behaviour is abstract and Subjective. Only petty offences where the term of punishment is less than 7 years of imprisonment or fine should be commutated. Thus, in such cases, Good behaviour can be measured on certain criteria. Prisoners should be engaged in Purposeful Activities for 7 hours a day. ${ }^{19}$ Key Performance Indicators have been devised which include targets for a number of prisoners who complete accredited offending behaviour programmes. Also, differential or incentive-based regimes, which are supposed to reward prisoners for good behaviour, have been developed. Thus, this mechanism in a formed structure can be implemented. 
An amendment can be brought to add a section 433A in Cr. P. C. where the term Good Behaviour can be made restrictive to certain petty offences and a criteria or mechanism to be given to measure it as suggested above. It can state that: "Prisoner, with punishment of imprisonment of or less than 7 years or with fine or both, can be commuted on grounds of good behaviour which can be measured by the set criteria incorporated in the prison manual."

Along with this, a criterion needs to be introduced in Prison Manual to measure good behaviour of a prisoner which can include Key Performance Indicators and Incentive based regimes.

\section{Training and development of prison personnel}

The Ministry of Home Affairs in a letter dated $25^{\text {th }}$ of February, 2020 had urged DGs/IGs of prisons to lay emphasis on reforming prisoners, so that they have a better life when they come out of jail after serving their sentence, for which they may be provided necessary training for attitudinal changes if necessary. The implementation of these guidelines cannot be ensured, especially because of the unprecedented pandemic situation. These advisories might be obliterated in the long-run.

Presently these are merely advisories, but these must be consolidated in the prison manuals for their effective implementation in actuality.

\section{CONCLUSION}

To improve the conditions of prisons and to protect the fundamental right to life of the prisoners as enshrined under Article 21 of the Indian Constitution, several guidelines have been given by the Supreme Court through various landmark judgements like Hussainara Khatoon $v$. State of Bihar (AIR 1360 SC 1979), Md. Giasuddin v. State of Andhra Pradesh (AIR 1926 SC 1977), D.B.M. Patnaik v. State of Andhra Pradesh (AIR 2092 SC 1974), Sheela Barse v. State of Maharashtra (AIR 378 SC 1983), Sunil Batra v. Delhi Administration (AIR 1675 SC 1978) and Prem Shankar v. Delhi Administration (AIR 1535 SC 1980). In lieu of the various guidelines, manuals and progressive committee reports, the Indian correctional system needs to be restructured in terms of inclusive Mental Health laws and provisions which still remain unexplored.

Funding: IMPRESS/P2778/Indian Council of Social Science Research Conflict of interest: None declared

Ethical approval: Not required

\section{REFERENCES}

1. Chambliss W. Corrections (Key Issues in Crime and Punishment). SAGE Publications. 1st ed. Thousand Oaks; 2011.

2. Harrendorf S, Heiskanen M, Malby S. International Statistics on Crime and Justice. European Institute for Crime Prevention and Control, Affiliated with the United Nations; 2010.

3. Prakash O, Sanger K, Sharma N, Singh A. Effect of Incarceration on Well Being of Prisoners: A Study among Convicted and Under-trials. Int $\mathbf{J}$ Indian Psychol. 2015;3(1).

4. Bhuyan N, Das T. Prevalence of Depression among the Under-Trial prisoners (UTPs) of Odisha. Indian J Health Well Being. 2012;3(3):750-3.

5. Agarwal S, Mitra P. Period of Imprisonment and Mental Well Being of Female Prisoners Inhabitant of Lucknow Jail, Uttar Pradesh, India. Res J Family Community Consumer Sci. 2017;5(1):1-7.

6. Scott D, Flynn N. Prisons and Punishment. SAGE Publications. 2nd ed. Thousand Oaks; 2008.

7. Partyka R. Stress and Coping Styles of Female Prison Inmates. Theses and Dissertations; 2001.

8. Hemmens C, Stohr M, Walsh A. Corrections (Reader Series in Criminology and Criminal Justice). SAGE Publications Ltd. 3rd ed. California; 2009.

9. Odisha State Legal Services Authority, Odisha. A Study on Prisons in Odisha, 2013. Available at: https://oslsa.nic.in/wpcontent/uploads/2019/08/JAIL-FINAL-BOOK.pdf. Accessed on 5th September 2020.

10. Singh DJ, Randhawa G. Analysis of Challenges faced by Indian Prisons System. IOSR J Humanities Social Sci. 2015;20(11).

11. Sinha S. Adjustment and Mental Health Problem in Prisoners. Industrial Psychiatry J. 2010;19(2):101-4.

12. Glaze L, James D. Mental Health Problems of Prison and Jail Inmates. Bureau Justice Statistics. 2006;104(12):2328-233.

13. Alam S, Das O, Lon Z. Relationship between Emotional Intelligence and Psychological Well Being of Male Police Personnel. Journal Indian Academy Applied Psychology. 2011;37(1):47-52.

14. Bayford J, Cowe F, Deering J. What Else Works: Creative Work with Offender. Oregon: Willian Publishing, SAGE J Publications; 2010.

15. Chauhan P, Hurt S, Loper A, Warren J. Exploring Prison Adjustment among Female Inmates: Issues of Measurement and Prediction. Criminal Justice Behaviour, SAGE Journal. 2004;31(5):624-45.

16. Anuoluwapo A, Kolawale B, Victoria B. Perceived Social Stigmatization and Coping Strategies as Predictors of Psychological Well Being among Female Partners of Prisoners. J Social Sci. 2014;10(1):15-25.

17. Picken J. The Coping Strategies, Adjustment and Well Being of Male Inmates in the Prison 
Environment. Internet J Criminology. 2012:192218.

18. National Crime Records Bureau, India. Prison Statistics in India, 2015. Available at: https://ncrb.gov.in/sites/default/files/PSI-2015\%2018-11-2016_0.pdf. Accessed on 10 September 2020.

19. Dass SR. Punishment and the Prison: Indian and International Perspectives. SAGE Publications. 1st ed. New Delhi; 2000.

Cite this article as: Mishra A, Shreya A, Shukla A. Promotion of mental health and well-being in Indian prisons. Int J Community Med Public Health 2021;8:482-8. 